\title{
The development of Smart Card-Based Media on the Beauty of Togetherness Themes in Class IV Elementary School of 026609, South Binjai District
}

\author{
Thessa Herdyana ${ }^{1}$, Hidayat ${ }^{2}$, Syarifah $^{2}$ \\ ${ }^{1}$ Master Student in State University of Medan (Unimed), Indonesia \\ ${ }^{2}$ State University of Medan (Unimed), Indonesia \\ thessagurusinga@yahoo.co.id
}

\begin{abstract}
This research is aimed to describe the development of smart card based media on the beauty of togetherness themes in class IV elementary school of 026609, South Binjai District. This research was carried out in stages from December to March. The subjects of this research were fourth grade students in elementary school of 026609, South Binjai District by taking as many as 28 students as a large group trial and 10 students for a small group trial. The object of the research is the smart card-based media which developed. This research found that the effectiveness of smart card-based media in improving student learning outcomes has been effectively used in learning, this can be seen from the results of the completeness of student learning in a classical manner on trial I or small group that obtained percentage of $90 \%$ and $76 \%$ of student response questionnaire and in trial II or large groups of learning outcomes is obtained a percentage of $86 \%$ and the results of student response questionnaire is obtained to $86.23 \%$.
\end{abstract}

Keyword : Smart card based media; the beauty of togetherness themes; student

\section{Introduction}

The development of learning devices which are valid, effective and practical are expected to be able to help achieve educational goals as expected. According to Nieveen (2007:26) "all components should be consistently linked to each other (construct validity)". So valid is the compatibility between the materials on the device developed with the needs of students. Then as for the effective device, according to him, it can be seen from the increase in student achievement after being given the learning device.

A learning device is said to be effective according to Nieveen (2007: 26) stating that "Using the intervention results in desired outcomes". So the effectiveness of learning devices is the use of the results of interventions to obtain the desired results.

Besides being valid and effective, the media which is developed must also be practical, according to Nieveen (2007: 26) stating that "the characteristics of high-quality interventions are that of end-users (for instance teachers and learners) easy for them to use materials that are compatible with the developers of intentions. Nieveen continued the three elements above (valid, effective, practical) are requirements that must be fulfilled so that the media can be said to be feasible to use.

\section{Review of Literatures}

\subsection{The Nature of Learning Media}

Learning media is the equipment used by teachers in the teaching and learning process. Learning media is needed to help facilitate the delivery of material. Some experts states the definition of media by Sri Anitah (2009: 1) explains that "the word media comes from Latin which is the plural and the word medium, which means something that is located in the middle (between two parties or poles) or a device. Media can also be interpreted as an intermediary or 
liaison between two parties, namely the source of the message with the recipient of the message or information. Therefore, learning media means something that delivers learning messages between message givers to message recipients ".

Whereas Azhar Arsyad (2007: 4) "Declares that media is a tool that conveys learning messages". According to Cucu Suhana Hanafiah (2010: 59) learning media is "All forms of stimulants and tools provided by teachers to teach students to learn quickly, precisely, easily, correctly and not the occurrence of verbalism". In addition to these opinions, According to Syaiful Bahri Djamarah (2010: 122) "Media is a tool in the teaching and learning process". Also clarified by Syaiful Bahri Djamarah (2010: 121) that "Media is any tool that is used as a channel message to achieve teaching goals".

Based on several opinions expressed by experts, it can be concluded that learning media are all tools used by teachers to deliver material to students in order to stimulate students to learn quickly, precisely, easily, correctly, so that learning objectives can be achieved.

\subsection{Smart Card Media}

The card is a rather thick rectangular paper used for various purposes (Isyono, 2006: 262). Meanwhile, according to the Big Indonesian Dictionary, a card is a small flat object, generally made of thick paper or plastic.

According to John D. Latuheru (1988: 41) card media is "Media viewpoints that are not projected. These media include: images, graphics, models and original objects ". This media card can be used as a tool for more effective communication in the learning process. Students are expected to understand the material conveyed by the trainer or teacher with the help of card media.

Smart card media is one of the print-based media. This learning media is useful for presenting memorization for the material presented. According to Winanti (2009: 43) "Smart cards are innovative creative game tools that are something that is used to play, which can activate children, which can be used in the learning process". Smart cards, which are teacher or child works made of cartoon paper, used paper, HVS paper, are given interesting images that are combined with the game of matching letters, words, numbers. Smart is smart, smart and proficient. Based on this understanding, smart card games are games that activate children to practice their creativity.

\subsection{Learning Outcomes}

Learning outcomes are the ultimate goal of implementing learning activities in school. Learning outcomes can be improved through conscious effort carried out systematically leading to positive change which is then called the learning process. The end of the learning process is the acquisition of a student learning outcome. Student learning outcomes in the class are collected in a set of class learning outcomes. All learning outcomes are the result of an interaction between learning and teaching. From the teacher's side, teaching action ends with the process of evaluating learning outcomes, while in terms of students, learning outcomes are the ending and the peak of the learning process (Dimyati and Mudjiono, 2009: 3).

According to Sudjana (2010: 22), learning outcomes are "Ability possessed by students after receiving learning experiences". Furthermore Warsito (in the Ministry of National Education, 2006: 125) argues that "The results of learning activities are characterized by a change in behavior towards a relatively permanent positive self-learning for people". In connection with that opinion, Wahidmurni. (2010: 18) explains that someone can be said to 
have succeeded in learning if he was able to show a change in him. These changes include in terms of thinking skills, skills, or attitude towards an object.

\subsection{Thematic Learning}

Integrated thematic learning is one of integrated learning model that uses themes to associate several subjects so as to provide meaningful experiences for students. Integrated learning is defined as learning that connects various ideas, concepts, skills, attitudes, and values, both between subjects and in one subject. Thematic learning emphasizes the selection of a specific theme that is in accordance with the subject matter, to teach one or several concepts that combine various information.

Thematic learning is defined as learning that is designed based on certain themes. Thematic learning provides the breadth and depth of curriculum implementation, offering students enormous opportunities to bring about dynamics in education.

Thematic learning is a learning approach that integrates various competencies and various subjects into various themes. Integration is carried out in two ways, namely integrative attitudes, skills and knowledge in the learning process and integrative various related basic concepts. The theme of knitting the meaning of various basic concepts so that students do not learn the basic concepts partially. Thus learning provides full meaning to students as reflected in the various themes available (Kurniawati and Wakhyudin, 2014: 60).

\section{Research Methods}

This research was conducted in class IV elementary school of 026609, South Binjai which is located in Sei Babalan Pujidadi Street, South Binjai District. This research was carried out in stages from December to March. The subjects of this research were fourth grade students in elementary school of 026609, South Binjai by taking as many as 28 students as a large group trial and 10 students for a small group trial. The object of research is the smart card-based media which developed.

\section{Discussion}

The development of smart card-based media in this study is in the form of media used in the teaching and learning process. Learning media is based on the ADDIE development model. The steps of the ADDIE model include aspects of Analyze, Design, Development, Implementation and Assessment.

Activities at this stage are analysis of student characteristics, curriculum analysis, which is then used as the basis for the formulation of smart card-based learning media developed. The analysis stages in this study include:

The analysis was carried out on the students of elementary school of 026609, South Binjai that is to find out the characteristics of students and to find out the advantages and disadvantages of the material studied with the learning media available at school. Characteristics of class IV students analyzed included cognitive development, background knowledge of students, and economic background.

Based on a review of the background of students' knowledge from the written results, it was found that many students did not know the cultural diversity in their area of residence (local environment). This is the impact of the use of media available in the class. The learning 
process in the class still uses the lecture method, namely the teacher explains then the students listen, take notes, and do the assignments according to the teacher's instructions, and each student has different characteristics, this can be seen from the questions given in various answers.

Based on some of the characteristics of the students, we need a learning media to overcome existing problems and curiosity of students in learning, especially the theme of the beauty of togetherness in class. Therefore, researchers develop smart card-based media in the learning process so that students can be more active in learning.

The material used in this study is the sub-theme of the beauty of togetherness for elementary school class IV which refers to the 2013 curriculum. In the competency analysis phase, researchers identify basic competency and competency standards needed in developing smart card-based learning media on the theme of beautiful togetherness.

\subsection{Description of the Design Phase (Design)}

After analyzing the media to be developed, the stages of developing smart card-based learning media are as follows:

1. Formulating the development of learning media

Designing smart card-based learning media arranged in sequence consisting of covers, card instructions and contents.

2. Development of smart card-based media

At this stage the initial design of smart card-based media was produced on the theme of the beautiful togetherness of the sub themes of my nation's cultural diversity in North Sumatra. This media is designed as a medium that can be used in learning activities. On smart card-based media there is a front page (Cover).

1) Start Page (cover)

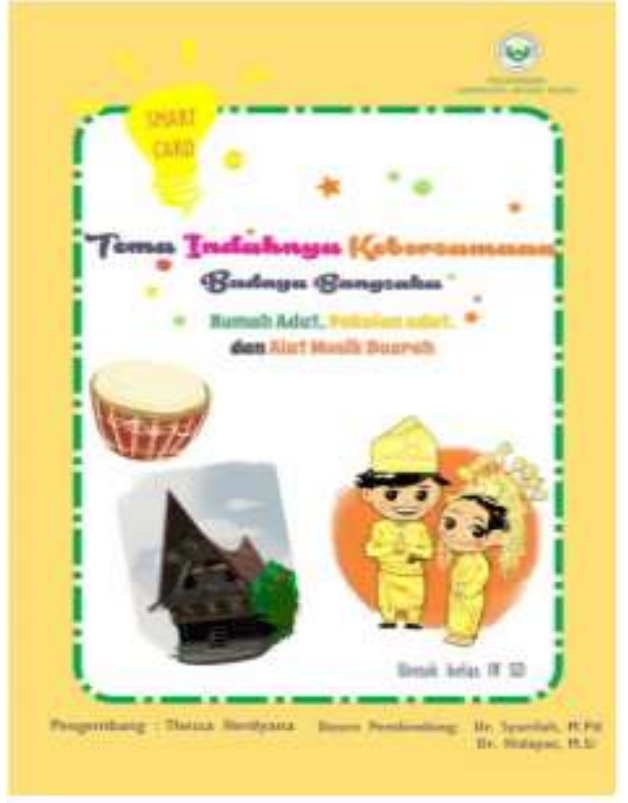

Figure 4.1 Cover of smart card-based media

Figure 4.1 shows that on the first page (cover) which is the outermost sheet designed in such a way as to reflect the contents entitled the beauty of togetherness theme, there are pictures of children who wear regional clothing in North Sumatra, Traditional Houses and Musical Instruments. 
2) Contents Display

The display of the contents of the smart card-based media is as follows:

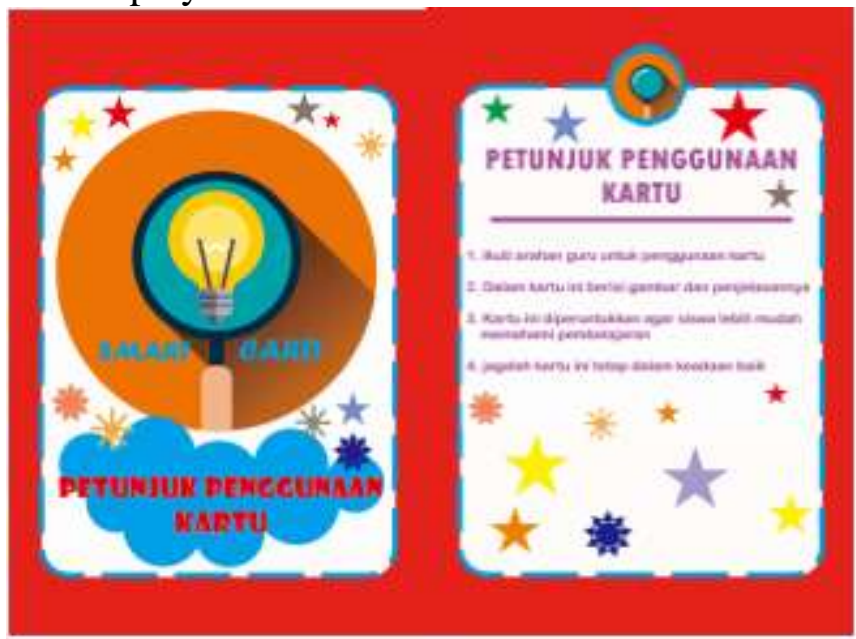

Instructions for Using Cards
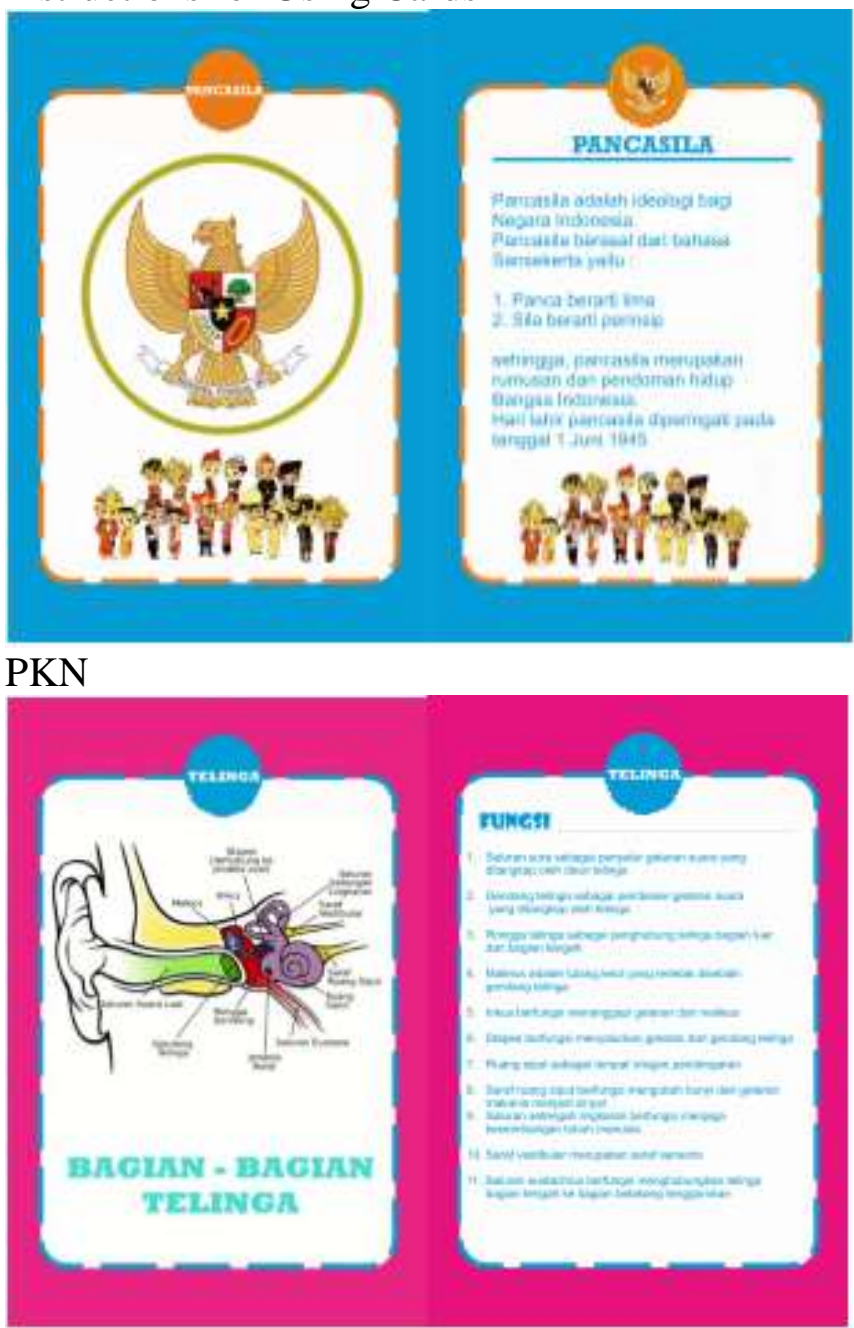

IPA 


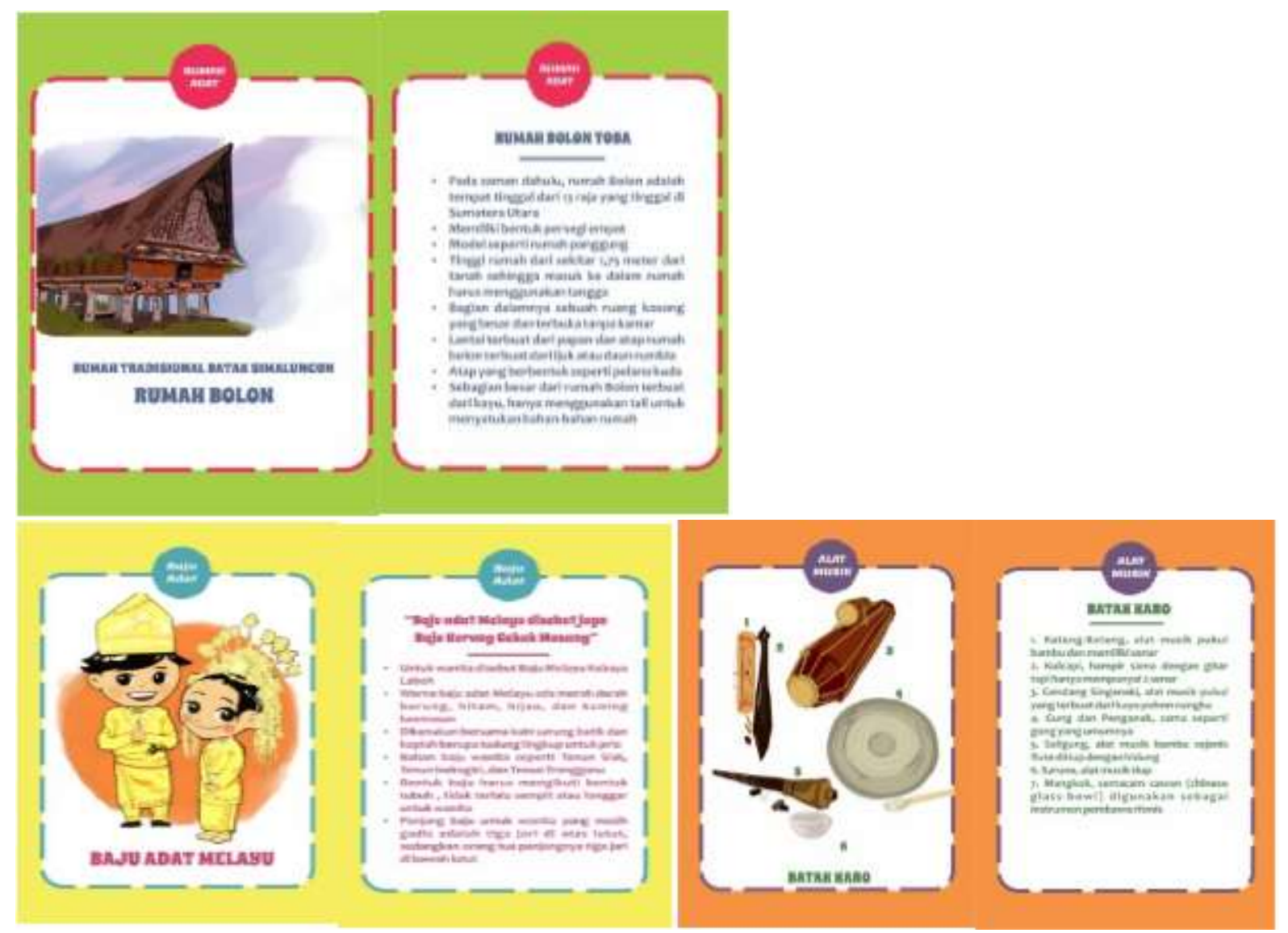

IPS

Figure 4.2 Smart Card Based Media Beautiful Theme Togetherness

\subsection{Description of the Development Phase (Development)}

The first stage of the development phase is to validate the draft I to the experts and then do a field trial. The expert validation focused on the feasibility of material content, the feasibility of the media, and the design feasibility of the smart card-based media developed. The results of expert validation are in the form of validation values, corrections and suggestions that are used as a basis for revising and improving the learning media developed. The cardbased media that has been revised is a media that has met the criteria valid and feasible to use in learning.

As a follow up to the design carried out in the design stage, the following steps are taken: Product Assessment Instrument. The data that obtained in this study are qualitative data and quantitative data. The data is obtained through two stages of assessment, namely expert validation and trial. Validation data on the smart card-based media developed was carried out by 3 (three) validators consisting of material expert validators, media experts and design experts.

Table 4.1 Results of Expert Evaluation of Validation Materials I and II

\begin{tabular}{|c|l|c|c|}
\hline No & Rating Item & \multicolumn{2}{|c|}{ Validation } \\
\cline { 3 - 4 } & & V1 & V2 \\
\hline 1 & Compatibility of material with RPP & 2 & 5 \\
\hline 2 & Conformity of material with core competencies & 3 & 5 \\
\hline 3 & Ease for understanding the contents of the card & 4 & 5 \\
\hline
\end{tabular}




\begin{tabular}{|c|l|c|c|}
\hline \multirow{2}{*}{ Ro } & Rating Item & \multicolumn{2}{|c|}{ Validation } \\
\cline { 3 - 4 } & & V1 & V2 \\
\hline 4 & Clarity in providing information on the card & 5 & 5 \\
\hline 5 & Card readability & 4 & 5 \\
\hline 6 & $\begin{array}{l}\text { Suitability of cards with Indonesian language } \\
\text { rules }\end{array}$ & 5 & 5 \\
\hline 7 & Effective and efficient use of language & 4 & 5 \\
\hline 8 & $\begin{array}{l}\text { The use of text that is interesting and leads to } \\
\text { understanding concepts }\end{array}$ & 4 & 5 \\
\hline 9 & The picture on the card becomes the center of & 4 & 4 \\
\hline 10 & The use of communicative language & 5 & 5 \\
\hline Total & 40 & 49 \\
\hline Average Score & $\mathbf{8 0} \%$ & $\mathbf{9 8} \%$ \\
\hline Criteria & V & $\mathbf{S V}$ \\
\hline
\end{tabular}

Based on the calculation of the table above, validation I produces $80 \%$ and after revision or validation II reaches $98 \%$ after adjusting to the table of eligibility criteria, then this score is included in the criteria are very valid or very feasible, but according to the material experts of the text used, and the picture on the card must be brighter so that the media is better to use without notes.

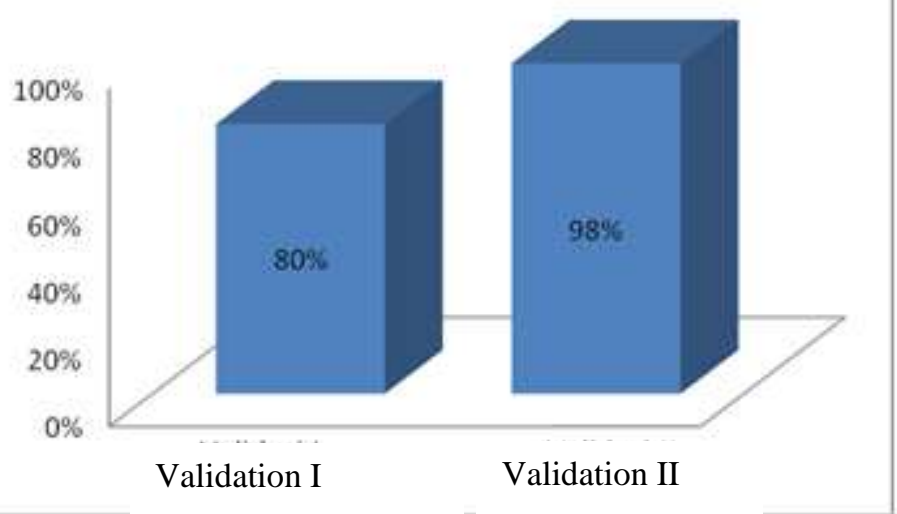

Figure 4.3 Bar Chart of the Results of Material Assessment

\section{Validation I and Validation II}

Based on the picture diagram above, it can be seen that the results of the material expert's assessment of Validation I and Validation II were increased. During the process of material expert validation in two stages of assessment and two product revisions, the average value of the media has increased. from the average score on the first validation that is $80 \%$ with valid criteria and increases to $98 \%$ with very valid criteria. The provision of research that media products are said to be feasible if at least included in the valid category, then smart card media products are feasible in terms of consideration of the content of the material. This is also reinforced by the material expert's statement that the material in this media is very feasible to use.

\section{Validation of Design Experts}


Design expert lecturer in the validation of smart card-based media "The Beauty ofl Togetherness" is Mr. Dr. Zulkifli, M.Sc who is a lecturer majoring in Fine Arts Education at Medan State University.

Table 4.2 Results of Evaluation of Validation Design Experts I and II

\begin{tabular}{|c|l|c|c|}
\hline No & \multicolumn{1}{|c|}{ Rating Item } & \multicolumn{2}{|c|}{ Validation } \\
\cline { 2 - 4 } & V1 & V2 \\
\hline 2 & Card size match with ISO standard A6 size & 4 & 4 \\
\hline & $\begin{array}{l}\text { Display elements of the image layout and writing on the card } \\
\text { has a unity (unity) }\end{array}$ & 3 & 5 \\
\hline 3 & $\begin{array}{l}\text { The appearance of the picture and writing layout gives the } \\
\text { impression of a good and harmonious rhythm }\end{array}$ & 3 & 5 \\
\hline 4 & A good view of the center of the image and writing on the card & 3 & 5 \\
\hline 5 & Size comparison of proportional layout elements & 3 & 5 \\
\hline 6 & Have a good contrast & 2 & 4 \\
\hline 7 & The image on the card becomes the center of view & 4 & 5 \\
\hline 8 & $\begin{array}{l}\text { Compatibility of writing colors contrasts with the background } \\
\text { color of the card }\end{array}$ & 3 & 4 \\
\hline 9 & $\begin{array}{l}\text { The comparison of the size of the writing with the image on } \\
\text { the card }\end{array}$ & 3 & 4 \\
\hline 10 & Fonts in writing are easy to read & 4 & 5 \\
\hline 11 & Do not use decorative letters / decorations & 4 & 5 \\
\hline 12 & Font type according to card designation & 4 & 5 \\
\hline 13 & Color selection on the card & 3 & 4 \\
\hline Total & 43 & 60 \\
\hline Average Score & 66,15 & 92,30 \\
\hline Criteria & V & SV \\
\hline
\end{tabular}

The data in the table above shows that the results of the validation of design experts in the first stage got an average score of 66.15 and after validation II reached 92.30. If it matches the eligibility criteria table, then this score is included in the criteria are very valid or feasible but according to the design experts the comparison of the elements of layout must be increased and the contrast of the image needs to be considered in more detail so that the media is suitable for use after revision.

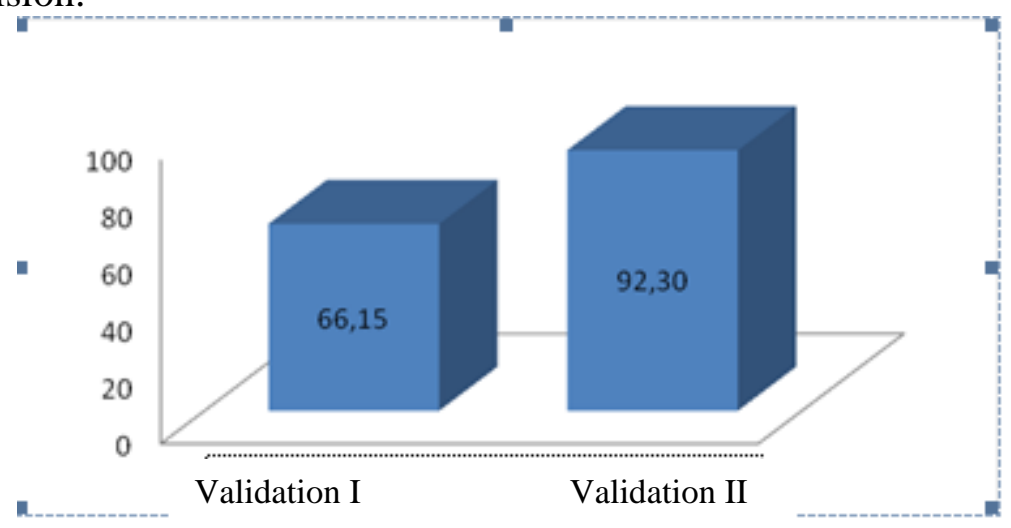

Figure 4.4 Bar Chart of the Results of Expert Evaluation of Validation I and II 


\section{Validation of Media Experts}

The assessment of the media is aimed at evaluating products on smart card-based media. Expert in the research expert is Mr. Dr. Daulat Saragi, M. Hum, who is a lecturer in the Department of Fine Arts Education at Medan State University.

Table 4.3 Results of Evaluation of Media Experts Validation I and II

\begin{tabular}{|c|l|c|c|}
\hline \multirow{2}{*}{ No } & \multicolumn{1}{|c|}{ Rating Item } & \multicolumn{2}{c|}{ Validation } \\
\cline { 2 - 4 } & & V1 & V2 \\
\hline 1 & Clarity of card usage instructions & 3 & 4 \\
\hline 2 & $\begin{array}{l}\text { Picture card capability for tools to understand and remember } \\
\text { information }\end{array}$ & 3 & 4 \\
\hline 3 & The ability of the picture card as a stimulus in learning & 4 & 5 \\
\hline 4 & The practicality of a picture card & 4 & 5 \\
\hline 5 & The ability of the picture card to create students' joy in learning & 3 & 4 \\
\hline 6 & The suitability of the picture card as a learning resource & 4 & 5 \\
\hline 7 & The suitability of picture cards with learning objectives & 4 & 5 \\
\hline 8 & Ease of picture cards in learning practices & 4 & 5 \\
\hline 9 & The suitability of picture cards with student characteristics & 3 & 4 \\
\hline 10 & The suitability of picture cards with learning environments & 4 & 5 \\
\hline 11 & Durability of card material & 3 & 5 \\
\hline Total & 39 & 51 \\
\hline Average Score & 70,90 & 92,72 \\
\hline Criteria & V & SV \\
\hline
\end{tabular}

Based on the data set 4.3 shows the results of the validation of the annual phase and stage II. In stage I the average score is 70.90 and after validation II it reaches 92.72. If it is matched with a table of eligibility criteria, this score is included in a very valid or very feasible criterion. However, according to media experts, the aspect of media usage must be adjusted for the age of the child from the color and card font elements.

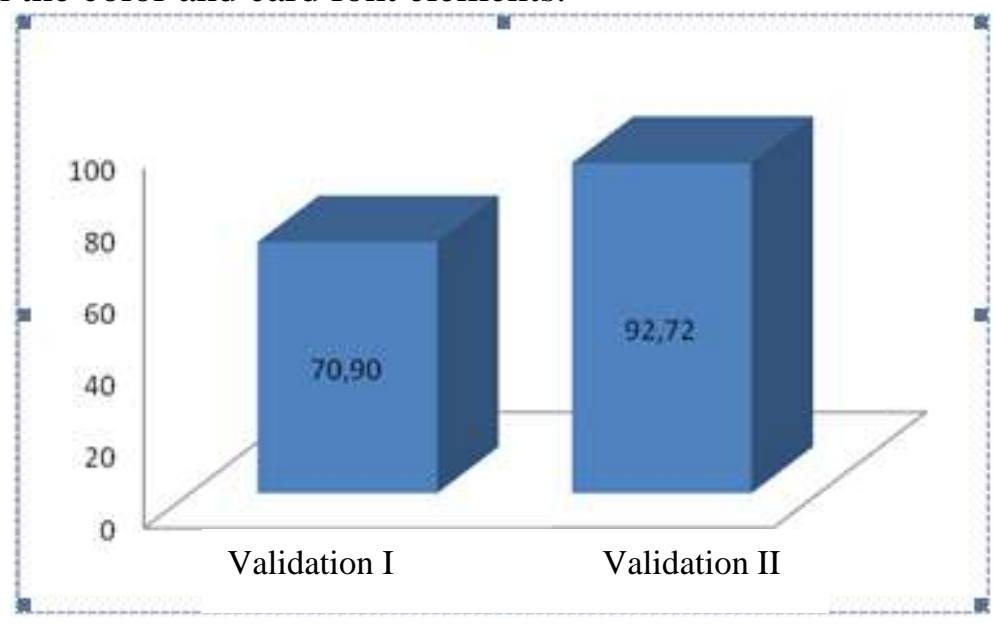

Figure 4.5 Bar Chart of the Results of Evaluation of Media Experts Validation I and II 


\section{Trial Small Groups}

a. Teacher Questionnaire Assessment Sheet

The small group test was carried out by involving 1 (one) teacher of grade IV-a (Ngaterin, S.Pd) in elementary school of 026609, South Binjai by giving teacher assessment sheets to smart card-based learning media in my national culture diversity sub-theme.

Table 4.4. Results of Teacher Questionnaire Assessment of Small Group

\begin{tabular}{|l|l|l|}
\hline Assessment Aspect & Assessment Indicator & Score \\
\hline \multirow{4}{*}{ Media } & Use of language in the media & 4 \\
\cline { 2 - 3 } & Use of images in the media & 5 \\
\cline { 2 - 3 } & Ease in using media & 5 \\
\cline { 2 - 3 } & Instructions for using media & 5 \\
\hline \multirow{2}{*}{ Learning } & Card Presentation & 4 \\
\hline Score & Accuracy of terms and use of sentences & 4 \\
\hline Average Score & Impact of Card use on students & 5 \\
\cline { 2 - 3 } & Constraints in using the Card & 5 \\
\hline Criteria & & $\mathbf{3 6}$ \\
\hline
\end{tabular}

Based on the databases 4.4 shows the average scores of practitioners' cards reaching 90. If matched with the table of eligibility criteria, this score is included in the criteria are very valid or very feasible to use fourth grade students of elementary school of 026609, South Binjai.

b. Student Response Questionnaire of Small Group

After the product revision stage based on the validation of material experts, media experts, design and park experts / teachers, the next step is to carry out product testing in small groups. The small group trial involved $10 \mathrm{IV}$-a class students in the Elementary School of 026609 South Binjai by using student response questionnaires which will be filled by students. The following data on student eligibility results can be seen in table 4.5 below:

Table 4.5 Results of Student Response Questionnaire of Small Group

\begin{tabular}{|l|l|l|l|l|l|l|l|l|l|l|l|l|l|}
\hline Student Code & $\mathbf{1}$ & $\mathbf{2}$ & $\mathbf{3}$ & $\mathbf{4}$ & $\mathbf{5}$ & $\mathbf{6}$ & $\mathbf{7}$ & $\mathbf{8}$ & $\mathbf{9}$ & $\mathbf{1 0}$ & $\mathbf{1 1}$ & tOTAL & $\begin{array}{l}\text { Percentag } \\
\text { e }\end{array}$ \\
\hline $\mathbf{1}$ & 5 & 3 & 3 & 3 & 4 & 4 & 4 & 4 & 3 & 4 & 4 & 41 & 74.54 \\
\hline $\mathbf{2}$ & 3 & 4 & 3 & 3 & 5 & 3 & 4 & 3 & 4 & 3 & 3 & 38 & 69.09 \\
\hline $\mathbf{3}$ & 4 & 4 & 3 & 3 & 4 & 3 & 4 & 3 & 3 & 3 & 3 & 37 & 67.27 \\
\hline $\mathbf{4}$ & 3 & 3 & 2 & 3 & 4 & 3 & 4 & 3 & 5 & 5 & 3 & 38 & 69.09 \\
\hline $\mathbf{5}$ & 4 & 4 & 3 & 4 & 4 & 3 & 4 & 4 & 3 & 4 & 4 & 41 & 74.54 \\
\hline $\mathbf{6}$ & 4 & 3 & 4 & 3 & 5 & 3 & 5 & 3 & 5 & 3 & 4 & 42 & 76.36 \\
\hline $\mathbf{7}$ & 3 & 4 & 4 & 5 & 5 & 4 & 4 & 5 & 3 & 3 & 3 & 43 & 78.18 \\
\hline $\mathbf{8}$ & 5 & 5 & 5 & 5 & 5 & 5 & 4 & 5 & 5 & 5 & 5 & 54 & 98.18 \\
\hline $\mathbf{9}$ & 4 & 4 & 4 & 4 & 4 & 4 & 4 & 4 & 4 & 4 & 4 & 44 & 80 \\
\hline
\end{tabular}




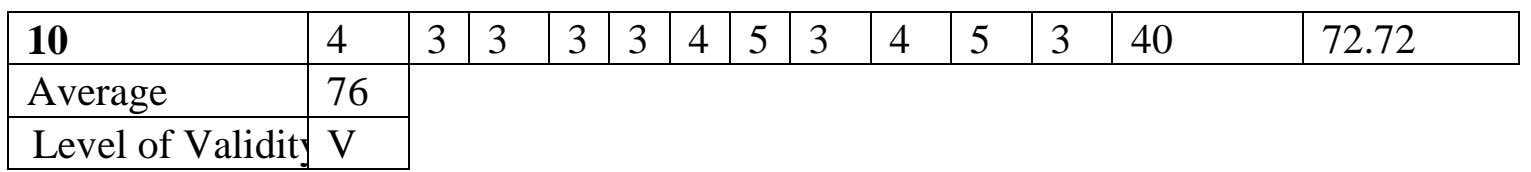

Considering the table 4.5 of the calculation above, the observations made by students after the learning process have reached a level of validity reaching $76 \%$. If it is matched with a table of eligibility criteria, then this score is included in the criteria of valid or feasible.

c. Small Group Learning Outcomes Test

The following is an assessment of student learning outcomes in small groups in class IV-a after the product has been tested for 1 week on the sub-themes of my nation's cultural diversity. The test was given in the form of 15 multiple choice tests and tested on 10 students. The following student learning outcomes are seen from completeness individually and classically.

Table 4.6 Calculation of Student Learning Outcomes Individually

\begin{tabular}{|l|l|l|l|l|}
\hline $\begin{array}{l}\text { Student } \\
\text { Number }\end{array}$ & Score obtained & KKM & Criteria & Predicate \\
\hline 01 & 60 & 70 & Not Pass & C \\
\hline 02 & 73 & 70 & Pass & B \\
\hline 03 & 73 & 70 & Pass & B \\
\hline 04 & 73 & 70 & Pass & B \\
\hline 05 & 86 & 70 & Pass & A \\
\hline 06 & 80 & 70 & Pass & B \\
\hline 07 & 73 & 70 & Pass & B \\
\hline 08 & 93 & 70 & Pass & A \\
\hline 09 & 80 & 70 & Pass & B \\
\hline 010 & 80 & 70 & Pass & B \\
\hline Total & $\mathbf{7 7 3}$ & & Pass & A \\
\cline { 1 - 2 } & $\mathbf{9 0 \%}$ & & & \\
\hline
\end{tabular}

\subsection{Phase of Product Implementation}

At the stage of application of smart card-based learning media that has been developed and declared feasible by material experts, design experts and media experts. So smart cardbased media can be implemented in teaching and learning activities. Large group trials were carried out in Public Elementary School of 026609 South Binjai class IV-b.

In the implementation of the use of smart card-based media, a large group trial will be conducted, namely 28 students, the learning process using smart card-based media, it appears that students are interested in completing learning using these media.

In the final stage of the meeting, the researcher gave 15 test questions in the form of multiple choice test questions. The results of these tests show student learning outcomes are increasing. This can be seen from the results of the student's learning test. After the last meeting of learning activities using smart card-based media researchers gave a questionnaire to students to find out students' responses to the use of the smart card-based media. 


\section{Trial Test for Large Group Learning Outcomes}

Test of Validity and Reliability of Learning Outcomes Tests

The research instrument used in this study was a test of student learning outcomes. After testing the application of the product in a large group of 28 samples, then the learning outcomes test was carried out and then tested the validity and reliability of the test. The instrumentes trial with a total of 15 questions about the number of questions, was carried out in the State Islamic Education class 026609 South Binjai. The score calculation for that score is 1 answer correctly and score 0 is answered. The validity of the knowledge is compared with the calculation of the values and the table, where the calculation is obtained from the results of the product correlation theory Pearson with the help of SPSS 22.0 for windows which is by correlating the item score with the total and wired scores obtained by significant variables $5 \%$. The purpose of this stage is to produce good research instruments, in the sense that they are valid and appropriate to use. From the calculation data with the SPSS 22.0 for windows program the results of the test validity are as follows:

Table 4.7 The Value of $r_{\text {count }}$ for The Test of Learning Outcomes

\begin{tabular}{|l|l|l|l|}
\hline $\begin{array}{l}\text { Question } \\
\text { Number }\end{array}$ & $\begin{array}{l}\text { Corrected Item - Correlation } \\
\text { Total }\end{array}$ & rtable & Information \\
\hline 1 & 0,392 & 0,374 & Low Valid \\
\hline 2 & 0,522 & 0,374 & Medium Valid \\
\hline 3 & 0,375 & 0,374 & Medium Valid \\
\hline 4 & 0,540 & 0,374 & Medium Valid \\
\hline 5 & 0,669 & 0,374 & Medium Valid \\
\hline 6 & 0,515 & 0,374 & Medium Valid \\
\hline 7 & 0,464 & 0,374 & Medium Valid \\
\hline 8 & 0,464 & 0,374 & Medium Valid \\
\hline 9 & 0,375 & 0,374 & Medium Valid \\
\hline 10 & 0,605 & 0,374 & Medium Valid \\
\hline 11 & 0,477 & 0,374 & Medium Valid \\
\hline 12 & 0,375 & 0,374 & Medium Valid \\
\hline 13 & 0,605 & 0,374 & Medium Valid \\
\hline 14 & 0,568 & 0,374 & Medium Valid \\
\hline 15 & 0,418 & 0,374 & Medium Valid \\
\hline
\end{tabular}

Based on the data in the table above, from 15 questions the learning outcomes test

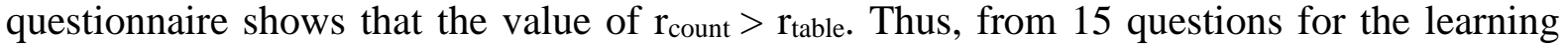
outcomes test, it is said to be valid.

The results of calculating reliability using the Cronbach's Alpha test are stated as follows:

Table 4.8. Reliability Calculation Results for Learning Outcomes Test 


Reliability Statistics
\begin{tabular}{|l|l|}
\hline $\begin{array}{l}\text { Cronbach's } \\
\text { Alpha }\end{array}$ & $\begin{array}{l}\text { Items } \\
\text { Items }\end{array}$ \\
\hline 709 & 15 \\
\hline
\end{tabular}

Based on the table above, it can be stated that 15 items for the student learning outcomes test are reliable because of alpha cronbach's $>r_{\text {table, }}$, where $0.709>0.374$.

1. Teacher Assessment Questionnaire of Large Group

The large group test was conducted by involving 1 (one) teacher of fourth grade (Khairunisa, S.Pd) in Elementary School of 026609 in South Binjai by providing teacher assessment sheets to smart card-based learning media in the sub-themes of my national cultural diversity. Data from the validation results by the teacher are shown in table 4.8 below.

Table 4.9 Results of Teacher Assessment Questionnaire of Large Group

\begin{tabular}{|l|l|l|}
\hline \multirow{3}{*}{ Assessment Aspect } & Assessment Indicator & Score \\
\hline \multirow{5}{*}{ Media } & Use of language in the media & 5 \\
\cline { 2 - 3 } & Use of images in the media & 5 \\
\cline { 2 - 3 } & Ease in using media & 5 \\
\cline { 2 - 3 } & Instructions for using media & 5 \\
\hline \multirow{2}{*}{ Mearning } & Card Presentation & 4 \\
\hline Total & Accuracy of terms and use of sentences & 4 \\
\hline Average Score & Impact of Card use on students & 5 \\
\cline { 2 - 3 } Criteria & Constraints in using the Card & 4 \\
\hline
\end{tabular}

Based on the data set 4.9 shows the average teacher questionnaire score reaches 92.5.If it is matched with a table of eligibility criteria, then this score is included in the criteria are very valid or very feasible to use fourth grade students of elemenary school of 026609 South Binjai.

2. Student Response Questionnaire of Large Group

Questionnaire responses of large groups of students involved 28 students of class IV-b in SD Negeri 026609 South Binjai using student response questionnaires to be filled out by students. The following are data on student eligibility results can be seen in table 4.10 below:

Table 4.10 Results of Student Response Questionnaire of Large Group

\begin{tabular}{|l|l|l|l|l|l|l|l|l|l|l|l|l|l|}
\hline $\begin{array}{l}\text { Student } \\
\text { Code }\end{array}$ & $\mathbf{1}$ & $\mathbf{2}$ & $\mathbf{3}$ & $\mathbf{4}$ & $\mathbf{5}$ & $\mathbf{6}$ & $\mathbf{7}$ & $\mathbf{8}$ & $\mathbf{9}$ & $\mathbf{1 0}$ & $\mathbf{1 1}$ & Total & Percentage \\
\hline 1 & 4 & 4 & 4 & 4 & 3 & 5 & 3 & 4 & 3 & 3 & 4 & 41 & 74.54 \\
\hline 2 & 5 & 5 & 5 & 4 & 4 & 5 & 4 & 3 & 4 & 3 & 3 & 45 & 81.81 \\
\hline 3 & 4 & 4 & 5 & 5 & 4 & 4 & 5 & 5 & 5 & 4 & 4 & 49 & 89.09 \\
\hline 4 & 4 & 5 & 4 & 4 & 5 & 4 & 4 & 5 & 5 & 4 & 4 & 48 & 87.27 \\
\hline
\end{tabular}




\begin{tabular}{|c|c|c|c|c|c|c|c|c|c|c|c|c|c|}
\hline 5 & 5 & 5 & 4 & 3 & 4 & 4 & 4 & 3 & 5 & 5 & 4 & 46 & 83.636 \\
\hline 6 & 5 & 4 & 5 & 5 & 5 & 5 & 5 & 4 & 5 & 5 & 5 & 53 & 96.36 \\
\hline 7 & 5 & 3 & 5 & 5 & 5 & 3 & 4 & 5 & 5 & 4 & 4 & 48 & 87.27 \\
\hline 8 & 4 & 5 & 4 & 4 & 4 & 5 & 4 & 3 & 4 & 4 & 5 & 46 & 83.63 \\
\hline 9 & 5 & 5 & 4 & 4 & 5 & 5 & 5 & 5 & 5 & 5 & 5 & 53 & 96.36 \\
\hline 10 & 3 & 5 & 4 & 5 & 4 & 4 & 4 & 5 & 4 & 4 & 4 & 46 & 83.63 \\
\hline 11 & 4 & 5 & 5 & 4 & 5 & 4 & 4 & 3 & 5 & 5 & 4 & 48 & 87.27 \\
\hline 12 & 4 & 5 & 4 & 4 & 4 & 5 & 5 & 3 & 4 & 5 & 4 & 47 & 85.45 \\
\hline 13 & 4 & 4 & 4 & 5 & 4 & 4 & 5 & 4 & 4 & 4 & 4 & 46 & 83.63 \\
\hline 14 & 3 & 5 & 4 & 3 & 4 & 4 & 5 & 5 & 5 & 5 & 4 & 47 & 85.45 \\
\hline 15 & 4 & 5 & 3 & 5 & 4 & 4 & 5 & 3 & 4 & 4 & 4 & 45 & 81.81 \\
\hline 16 & 4 & 3 & 5 & 4 & 5 & 5 & 3 & 5 & 4 & 5 & 5 & 48 & 87.27 \\
\hline 17 & 4 & 5 & 4 & 5 & 5 & 4 & 5 & 5 & 4 & 3 & 3 & 47 & 85.45 \\
\hline 18 & 5 & 4 & 4 & 4 & 5 & 4 & 4 & 5 & 5 & 5 & 3 & 48 & 87.27 \\
\hline 19 & 5 & 4 & 5 & 4 & 4 & 5 & 3 & 4 & 5 & 5 & 3 & 47 & 85.45 \\
\hline 20 & 5 & 4 & 5 & 4 & 4 & 5 & 5 & 5 & 5 & 3 & 4 & 49 & 89.09 \\
\hline 21 & 5 & 3 & 5 & 5 & 4 & 5 & 5 & 4 & 4 & 5 & 3 & 48 & 87.27 \\
\hline 22 & 5 & 5 & 4 & 3 & 3 & 5 & 4 & 5 & 4 & 4 & 4 & 46 & 83.63 \\
\hline 23 & 5 & 5 & 5 & 4 & 5 & 4 & 5 & 4 & 5 & 4 & 5 & 51 & 92.72 \\
\hline 24 & 3 & 3 & 5 & 5 & 5 & 5 & 3 & 5 & 5 & 3 & 4 & 46 & 83.63 \\
\hline 25 & 4 & 5 & 4 & 4 & 5 & 4 & 4 & 4 & 5 & 4 & 4 & 47 & 85.45 \\
\hline 26 & 4 & 5 & 3 & 5 & 5 & 4 & 3 & 4 & 5 & 5 & 4 & 47 & 85.45 \\
\hline 27 & 5 & 5 & 4 & 4 & 5 & 5 & 3 & 3 & 3 & 4 & 4 & 45 & 81.81 \\
\hline 28 & 5 & 5 & 4 & 4 & 4 & 5 & 5 & 5 & 4 & 5 & 5 & 51 & 92.72 \\
\hline Average & 86.23 & & & & & & & & & & & & \\
\hline $\begin{array}{l}\text { Level of } \\
\text { Validity }\end{array}$ & SV & & & & & & & & & & & & \\
\hline
\end{tabular}

Considering the above calculations, the observations made by students after the learning process obtained a level of validity reaching $86.23 \%$. If it is matched with a table of eligibility criteria, this score is included in the criteria as very valid or feasible.

3. Assessment of Learning Outcomes Test of Large Group

Table 4.11 Calculation of Test Results for Large Groups

\begin{tabular}{|l|l|l|l|l|}
\hline $\begin{array}{l}\text { Student } \\
\text { Number }\end{array}$ & Score obtained & KKM & Criteria & Predikat \\
\hline 01 & 60 & 70 & Not Pass & C \\
\hline 02 & 86 & 70 & Pass & A \\
\hline 03 & 93 & 70 & Pass & A \\
\hline 04 & 100 & 70 & Pass & A \\
\hline 05 & 93 & 70 & Pass & A \\
\hline
\end{tabular}




\begin{tabular}{|c|c|c|c|c|}
\hline 06 & 100 & 70 & Pass & A \\
\hline 07 & 100 & 70 & Pass & $\mathrm{A}$ \\
\hline 08 & 80 & 70 & Pass & $\mathrm{B}$ \\
\hline 09 & 86 & 70 & Pass & $\mathrm{A}$ \\
\hline 010 & 100 & 70 & Pass & $\mathrm{A}$ \\
\hline 011 & 63 & 70 & Pass & $\mathrm{C}$ \\
\hline 012 & 80 & 70 & Pass & $\mathrm{B}$ \\
\hline 013 & 93 & 70 & Pass & A \\
\hline 014 & 93 & 70 & Pass & A \\
\hline 015 & 100 & 70 & Pass & A \\
\hline 016 & 80 & 70 & Pass & B \\
\hline 017 & 93 & 70 & Pass & $\mathrm{A}$ \\
\hline 018 & 86 & 70 & Pass & A \\
\hline 019 & 93 & 70 & Pass & $\mathrm{A}$ \\
\hline 020 & 53 & 70 & Not Pass & $\mathrm{D}$ \\
\hline 021 & 100 & 70 & Pass & $\mathrm{A}$ \\
\hline 022 & 100 & 70 & Pass & $\mathrm{A}$ \\
\hline 023 & 60 & 70 & Not Pass & $\mathrm{C}$ \\
\hline 024 & 53 & 70 & Not Pass & $\mathrm{C}$ \\
\hline 025 & 100 & 70 & Pass & $\mathrm{A}$ \\
\hline 026 & 86 & 70 & Pass & $\mathrm{A}$ \\
\hline 027 & 100 & 70 & Pass & $\mathrm{A}$ \\
\hline 028 & 100 & 70 & Pass & $\mathrm{A}$ \\
\hline Total & \multicolumn{2}{|l|}{2461} & \multirow[t]{2}{*}{ Pass } & \multirow[t]{2}{*}{ A } \\
\hline PKK & $86 \%$ & & & \\
\hline
\end{tabular}

Calculating Classical Learning Completeness

$\mathrm{PKK}=\frac{\text { many students } y \text { an } K B \geq 85 \%}{\text { many research Subject }} \times 100 \%$

$\mathrm{PKK}=\frac{24}{28} \times 100 \%$

$\mathrm{PKK}=86 \%$

From the test results of learning that have been done in large groups can be seen that students who have completed or above the KKM numbered 24 people, and students who did not complete as many as 4 people.

\subsection{Evaluation Stage}

The final stage of the ADDIE development model is evaluation, which researchers did by analyzing the research data obtained, namely validity analysis from expert lecturers, teacher questionnaires, student response questionnaires and effectiveness of student learning outcomes tests. Data from expert validation results were used to determine the feasibility of smart cardbased media reviewed from material experts, media experts, and design experts, teacher questionnaires and student response questionnaires. Student response questionnaire data is used to determine student responses or student responses to smart card-based media developed in the learning process in the classroom. And student learning outcomes tests are used to determine the effectiveness of smart card-based media in the learning process. 
1. Analysis of Feasibility Data on Smart Card-Based Media

a. Validation Data Analysis by Experts

The results of expert validation data can be seen and illustrated in the tables and figures below.

Table 4.12 Expert Validation Analysis

\begin{tabular}{|l|l|l|l|}
\hline No & Validation & $\begin{array}{l}\text { Score } \\
\text { obtained }\end{array}$ & $\begin{array}{l}\text { Eligibility } \\
\text { Criteria }\end{array}$ \\
\hline 1 & Material Expert & 98 & SV \\
\hline 2 & Design expert & 92,5 & SV \\
\hline 3 & Media Expert & 91,25 & SV \\
\hline \multicolumn{2}{|l|}{ Average Score } & 93,91 & SV \\
\hline
\end{tabular}

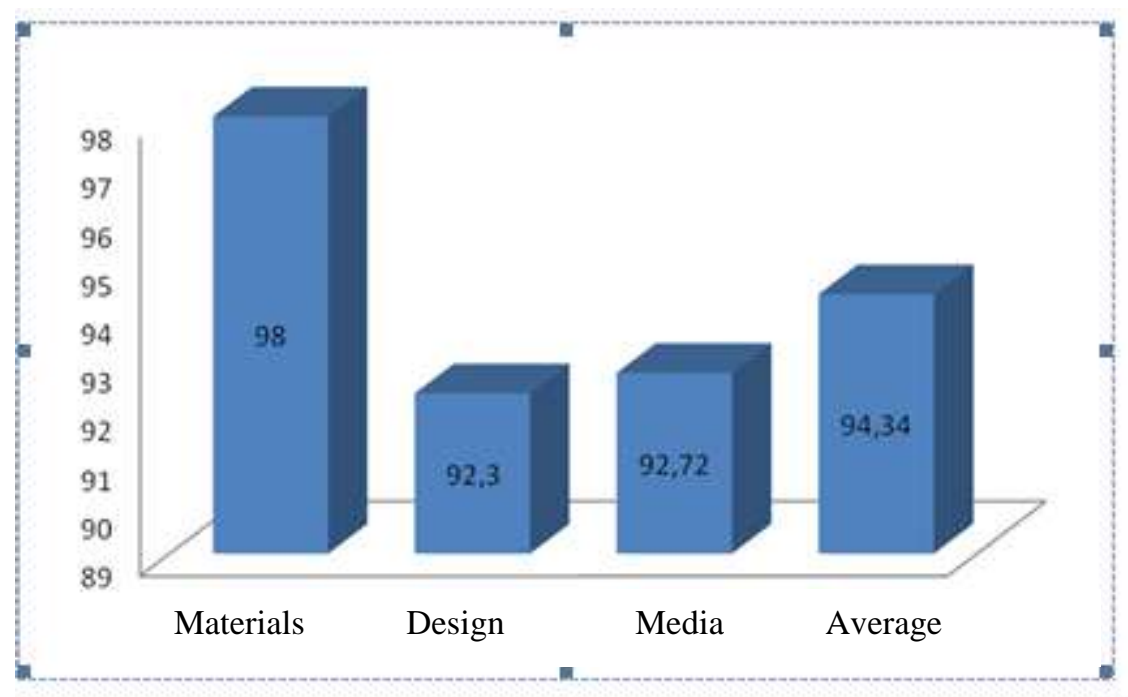

Figure 4.6 Expert Validation Assessment Analysis

b. Teacher Questionnaire Data Analysis

Smart card-based media developed, also validated to grade IV-a teachers and class IV-b teachers in Public Elementary School 026609. In general, the overall average score of teacher assessment sheets is 91.25 with very valid criteria. Data from the validation results by the teacher are shown in the table and figure below:

Table 4.13 Analysis of Teacher Questionnaire Assessment

\begin{tabular}{|l|l|l|l|}
\hline No & Group & Score obtained & $\begin{array}{l}\text { Eligibility } \\
\text { Criteria }\end{array}$ \\
\hline 1 & Small Group & 90 & SV \\
\hline 2 & Large group & 92,5 & SV \\
\hline Average Score & 91,25 & SV \\
\hline
\end{tabular}




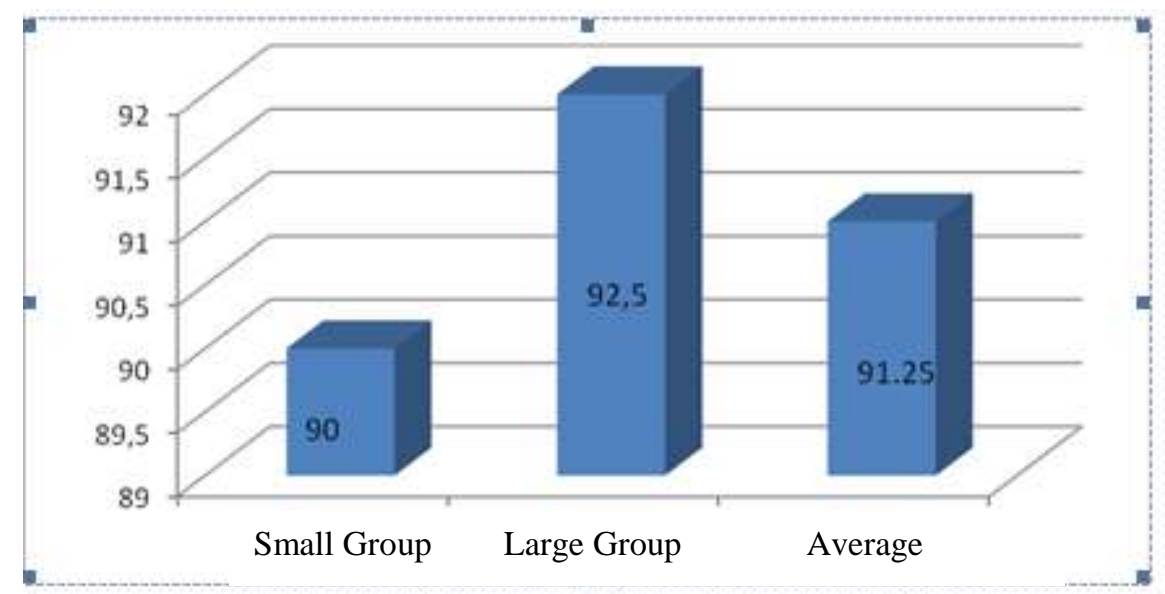

Figure 4.7. Analysis of Teacher Questionnaire Assessment

2. Analysis of the Effectiveness on Smart Card Based Media

The Analysis of the Effectiveness of Smart Card Based Media developed is analyzed using (1) Learning success or learning completeness and (2) student response. The effectiveness of the use of the smart card-based media developed is achieved when fulfilling the two indicators, with the condition that the success of learning or student completeness is complete.

a. Student Learning Completeness Analysis

Tests of learning outcomes obtained are then analyzed by researchers to see the completeness of students in learning in an internal and classical manner. Student learning outcomes can be seen in the table and figure below.

Table 4.14 Analysis of Student Learning Outcomes Test

\begin{tabular}{|l|l|l|l|}
\hline No & Group & Score obtained & $\begin{array}{l}\text { Eligibility } \\
\text { Criteria }\end{array}$ \\
\hline 1 & Small Group & $90 \%$ & SV \\
\hline 2 & Large group & $86 \%$ & SV \\
\hline \multicolumn{2}{|l}{ Rata-rata Skor } & $88 \%$ & SV \\
\hline
\end{tabular}

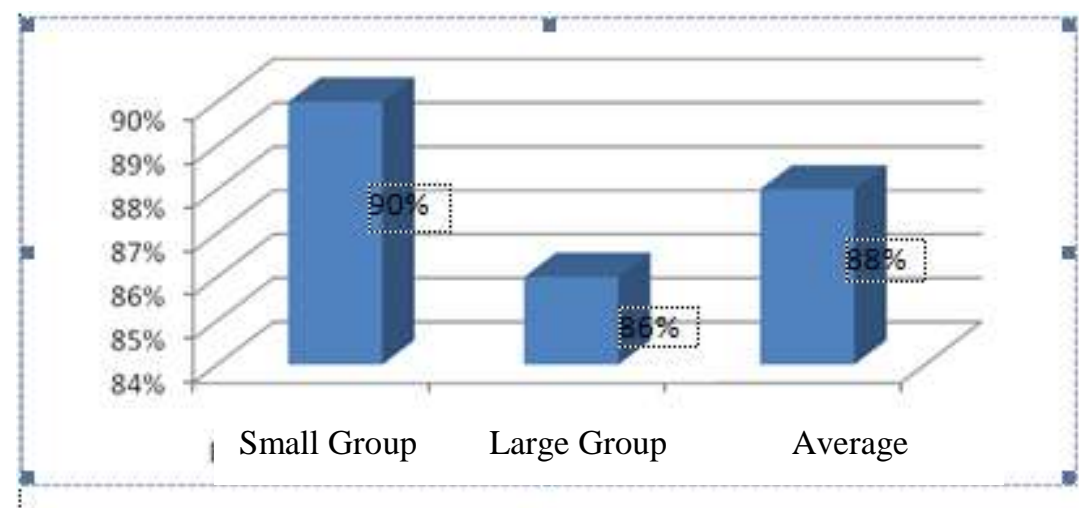

Figure 4.8 Analysis of Student Learning Outcomes Test 
The effectiveness of learning media is determined based on the achievement of completeness of student learning outcomes in a classical manner. A class is said to complete learning if PKK is $\geq 85 \%$. Data obtained from student learning outcomes at the end of each trial were analyzed to determine the percentage of students who had achieved their learning outcomes. From the small group test data, it was obtained that the PKK value reached $90 \%$ and the large group that had been carried out obtained a PKK value of $86 \%$. And from both the values of small groups and large groups can be averaged by $88 \%$. It can be said that the value of learning outcomes using smart card-based media has been completed and effectively used by fourth grade students.

b. Student Response Questionnaire Analysis

Table 4.15 Student Response Analysis

\begin{tabular}{|l|l|l|l|}
\hline No & Group & Score obtained & $\begin{array}{l}\text { Eligibility } \\
\text { Criteria }\end{array}$ \\
\hline 1 & Small Group & $76 \%$ & V \\
\hline 2 & Large Group & $86,23 \%$ & SV \\
\hline \multicolumn{2}{|l|}{ Average Score } & $81,12 \%$ & SV \\
\hline
\end{tabular}
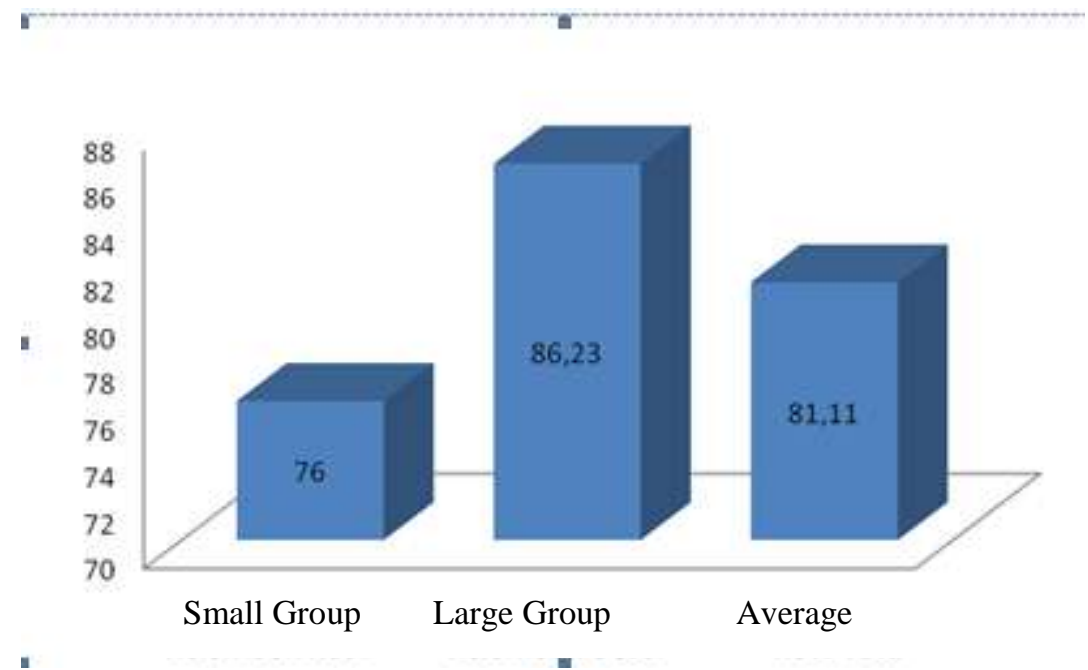

Figure 4.9 Student Response Analysis

\section{Conclusion}

The developed media has been feasible to use in classroom learning, this can be seen from the results of the feasibility test of smart card-based media which includes material experts obtaining a score of 98, design experts is obtained 92.30, and media experts is obtained 92.72 in the very valid. The effectiveness of smart card-based media in improving student learning outcomes has been effectively used in learning, this can be seen from the results of the completeness of student learning in a classical manner on trial I or small group that obtained percentage of $90 \%$ and $76 \%$ of student response questionnaire and in trial II or large groups of learning outcomes is obtained a percentage of $86 \%$ and the results of student response questionnaire is obtained to $86.23 \%$. 


\section{References}

Ahmad Rivai, Nana Sudjana. 2013. Media Pengajaran. Bandung : Sinar Baru Algensindo. Aqip, Zainal. At el. 2010. Penelitian Tindakan Kelas. Bandung.Yrama Widia Anitah, Sri. 2008. Media Pembelajaran. Surakarta: UNS Press Arikunto, S. 2010. Prosedur Penelitian Suatu Pendekatan Praktek. Jakarta: Rineka Cipta. Arif Sadiman S, 2009. Media Pendidikan. Jakarta. Rajawali Pers.

Akbar Sa'adun. Instrumen Perangkat Pembelajaran. Bandung: Remaja Rosdakarya.

Aqib, Zainal. 2013. Model-model, Media, dan Strategi Pembelajaran Kontekstual (Inovatif).

Bandung : Yrama Widya.

Arsyad Azhar. 2007. Media Pembelajaran. Jakarta: PT Raja Grafindo Persada. 2011. Media Pembelajaran. Jakarta: Rajawali Pers. 2015. Media Pembelajaran. Depok: PT Rajagrafindo Persada.

Bahri Djamarah, Syaiful. 2010. Psikologi Belajar. Jakarta : Rineka Cipta.

Dimyati and Mudjiono. 2009. Belajar dan Pembelajaran. Jakarta: PT Rineka Cipta.

Depdiknas. 2006. Bunga Rampai Keberhasilan Guru dalam Pembelajaran (SMA, SMK, dan SLB). Jakarta: Depdiknas. 2003. Undang-Undang RI Nomor 20 Tahun 2003, tentang Sistem Pendidikan Nasional.

Gulo, W. 2002. Strategi Belajar Mengajar. Jakarta: PT Grasindo.

Hanafiah, cucu suhana.2009. Konsep Strategi Pembelajaran.Bandung: Refika Aditama.

Hamalik, Oemar. 2008. Kurikulum dan Pembelajaran. Jakarta: Sinar Grafika 2006. Proses Belajar Mengajar. Jakarta: PT Bumi Aksara

Hidayati. (2002). Pendidikan Ilmu Pengetahuan Sosial di SD. Yogyakarta : UNY.

Indriana, D. 2011. Ragam Alat Bantu Media Pengajaran. Yogyakarta: Diva Press. Ibrahim 2011. Kurikulum dan Pembelajaran. Jakarta : Rajagrafindo Persada.

John D. Latuheru. (1988). Media Pembelajaran. Jakarta :Depdikbud.

Januszewski, A., Molenda, M. 2008. Educational Technology. New York \& London: Routledge Taylor \& Francis Group.

Kunandar. 2013. Penilaian Autentik (Penilaian Hasil Belajar Peserta Didik Berdasarkan Kurukulum 2013). Raja Grafindo. Bandung.

Komalasari, Kokom. 2011. Pembelajaran Kontekstual Konsep dan Aplikasi Bandung : Refika aditama.

Kurniawati, Ika Diah and Husni Wakhyudin. 2014. Efektivitas Model Think Pair Share Dalam Pembelajaran Tematik Integratif Terhadap Kemampuan Pemecahan Masalah. Universitas PGRI Semarang. Volume 4 No. 1 July 2014. Accessed on 6 August 2018.

Mulyasa. 2013. Pengembangan Dan Implementasi Kurikulum 2013. Jakarta : Rosda

Maryani, Enok. 2009. Pengembangan Program Pembelajaran IPS untuk Meningnkatkan Keterampilan Sosial. Jakarta: Alfabeta.

Marzano. Robert J, John S. Kendall. 2007. The New Taxonomi of Educational Objectives. Corwins Press A SAGE Publications Company : United Kingdom.

Muhibbinsyah.2013. Psikologi Pendidikan dengan Pendekatan Baru. Jakarta: PT Remaja Rosdakaraya.

Nieveen, N. 2007. Prototyping to Reach Product Quality in Plomp, T;

Nieveen, N;Gustafson, K; Branch, R.M; and van den Akker, J (eds). Design Approaches and Tools in Education and Training . London: Kluwer Academic Publisher. 
Prastowo, Andi. 2014. Pemenuhan Kebutuhan Psikologis Peserta Didik SD/MI Melalui Pembelajaran Tematik-Terpadu. UIN Sunan Kalijaga Yogyakarta. Journal of Pendidikan Sekolah Dasar, Volume 1, No 1, August 2014. Accessed on 6 August 2018. Plomp, Tj. 2007. Educational Design: Introduction. From Tjeerd Plomp (eds).Educational \& Training System Design: Introduction. Design of Education and Training (in Dutch).Utrecht (the Netherlands): Lemma. Netherland .Faculty of Educational Science and Technology, University of Twente.

Reffiane, Fine and Ernawati Saptaningrum. 2011. Model Pembelajaran Aktif Kreatif Efektif Menyenangkan Melalui Pendekatan Tematik Untuk Pembelajaran Sains Sekolah Dasar. Jurnal. Volume 1 No. 1 July 2011. Accessed on 6 August 2018.

Rusman.2015. Pembelajaran Tematik Terpadu : Teori, Praktik dan Penilaian. Jakarta : Rajagrafindo.

Sanjaya, Wina. 2012. Starategi pembelajaran berorientasi standar proses pendidikan. Jakarta : Kencana Prenada Media Grup.

Sapriya. 2009. Pendidikan IPS. Bandung: PT Remaja Rosdakarya.

Slameto. 2013. Belajar dan Faktor-Faktor yang Mempengaruhinya. Jakarta: Rineka Cipta

Slavin, Robert E. 2005. Cooperatife Learning: theory, research and Practice (N Yusron. Translated). London: A Allymand Bacot. The origin of the book is publicated in 2005.

Sudjana, Nana and Ibrahim. 2007. Media pembelajaran (penggunaan dan pembuatannya). Bandung: Sinar Baru Algensindo.

Sudjana. 2007. Media Pengajaran. Bandung: Sinar Algasindo.

Sugiyono. (2012). Metode Penelitian Kuantitatif, Kualitatif, dan R\&D. 17 Print. Bandung: Alfabeta.

Sugiyono. 2013. Metode Penelitian Pendidikan: Pendekatan Kuantitatif, Kualitatif, dan R\&D. Bandung: Alfabeta.

Suharsimi Arikunto at el. 2009. Penelitian Tindakan Kelas. Jakarta: Bumi.

Suherman. 2001. Strategi Pembelajaran Matematika Kontemporer. Bandung: UPI

Sukandi, Ujang. 2003. Belajar Aktif \& Terpadu. Surabaya: Duta Graha Pustaka.

Suprihatiningrum, Jamil. 2013. Strategi Pembelajaran. Yogyakarta: Ar-Ruzz Media.

Suprihadi Saputro, Zainul Abidin \& I Wayan Sutama. 2000. Strategi Pembelajaran, Bahan Sajian Program Pendidikan Akta Mengajar. Malang: Departemen Pendidikan Nasional, Fakultas Ilmu Pendidikan, Universitas Negeri Malang.Jakarta: Bumi Aksara.

Suprijono, Agus.2012. Cooperative Learning. Yogyakarta : Pustaka Pelajar, 2012.

Susanto, Ahmad. 2013. Pengembangan Pembelajaran IPS di Sekolah Dasar. Jakarta: Prenadamedia Group.

Susanto, Ahmad.2013. Pengembangan Pembelajaran IPS di Sekolah Dasar. Jakarta: Kencana. Trianto. 2011. Mendesaian Model Pembelajaran Inovatif Progresif. Edisi Ke-4. Jakarta: Kencana. 2012. Model Pembelajaran Terpadu. Jakarta: PT Bumi Aksara. 2007. Model Pembelajaran Terpadu dalam Teori dan Praktek. Jakarta: Prestasi Pustaka Publisher

Tasrif. 2008. Pengantar Dasar IPS. Yogjakarta: Genta.

Wahidmurni, Alifin Mustikawan, dan Ali Ridho. 2010. Evaluasi Pembelajaran: Kompetensi dan Praktik. Yogyakarta: Nuha Letera 